\title{
THE EFFECT OF EXPORTS ON A WEALTH OF A COUNTRY: A COMMENT ON THE ROLE OF NATURAL CAPITAL IN THE AMAZON BASIN
}

\author{
O EFEITO DAS EXPORTAÇÕES NA RIQUEZA DE UM PAÍS: COMENTÁRIOS \\ SOBRE O PAPEL DO CAPITAL NATURAL NA BACIA AMAZÔNICA
}

\section{EL EFECTO DE LAS EXPORTACIONES EN LA RIQUEZA DE UN PAÍS: COMENTARIOS SOBRE EL PAPEL DEL CAPITAL NATURAL EN LA CUENCA AMAZÓNICA}

Recebido em: 25 de junho de 2020

Aprovado em: 27 de Agosto de 2020

\begin{abstract}
This article examines the relevance of natural capital in a country's economy and what is the impact caused by exports, especially in natural resources, can have on the health of the economy and its accumulation of wealth. Natural capital, in this way, is of double significance, as it contributes to a country's set of fixed capital, also understood as part of its assets, in addition to assisting in the calculation of the impacts in the environment, that are not always reversible. The discussion is performed through a rescue of the main scientific articles related to the theme. This study is relevant given the current moment when natural resources are proven to be scarcer and their impacts are felt both in the economy and in the well-being of society, specially at the Amazon area, considered by many as the lungs of the world.
\end{abstract}

Keywords: Natural capital; Resource curse; Trade; Sustainable development.

RESUMO: Este artigo traz uma discussão sobre a relevância do capital natural na economia de um país e qual o impacto que as exportações, principalmente de recursos naturais, podem causar na saúde da economia e no seu acúmulo de riqueza. O capital natural, desta forma, tem importância dupla, ao contribuir para o conjunto de capital fixo de um país, também entendido como parte de seu ativo, além de auxiliar no cálculo dos impactos que nem sempre são reversíveis no meio ambiente. A discussão é feita através de um resgate dos principais artigos científicos relacionados à temática. Este estudo é relevante diante do momento atual em que recursos naturais tornam-se comprovadamente mais escassos e seus impactos são sentidos tanto na economia como no bem-estar da sociedade, principalmente na região Amazônica, considerada o pulmão do mundo.

\footnotetext{
${ }^{1}$ Mestrado (2016) e Doutoranda (previsão para 2021) em Comércio Internacional/Economia - Huazhong University of Science and Tecjnology - Wuhan, China. Graduação em Administração - Unidade de Ensino Dom Bosco (2008). Graduação em Turismo pela Faculdade Atenas Maranhense (2006). E-mail: santos.indira@gmail.com.
} 
Palavras-chave: Capital natural; Maldição dos recursos naturais; Comércio Exterior; Desenvolvimento sustentável.

RESUMEN: Este artículo trae una discusión sobre la relevancia del capital natural en la economía de un país y el impacto que las exportaciones, principalmente de recursos naturales, pueden tener en la salud de la economía y en su acumulación de riqueza. El capital natural, de esta manera, tiene una doble importancia al contribuir al conjunto de capital fijo de un país, entendido también como parte de sus activos, además de ayudar en el cálculo de los impactos no siempre reversibles en el medio ambiente. La discusión se realiza a través de un rescate de los principales artículos científicos relacionados con el tema. Este estudio es relevante ante el momento actual en el que los recursos naturales se han vuelto más escasos y sus impactos se sienten tanto en la economía como en el bienestar de la sociedad, principalmente en la región amazónica, considerada el pulmón del mundo.

Palabras clave: Capital natural; Maldición de los recursos naturales; Comercio exterior; Desarrollo sostenible.

\section{INTRODUCTION}

Following almost 200 years after the industrial revolution, the society at last noticed the impact those activities had in the nature and how it may affect the well-being of humans. The idea of conservation of the nature, comes from the idea of exploring its resources through sustainable practices in the attempt to balance the impact it has on the environment. The Declaration of the United Nations Conference on the Human Environment adopted on June 6 of 1972 is the first international law document to recognize the human right to a quality environment, which is one that allows humans to live with dignity. Since then, the discussion continued, and academics and countries started to develop ways to explore the resources without harming the environment. Alongside these studies, it has been also developed the idea that natural resources are part of the fixed capital of a country and, as so, they should be correctly addressed so then it can contribute to the development of a country.

Because of the geographical distribution of resources around the world, the economic activity also got affected, creating a situation where some places had a natural comparative advantage and started to provide materials to the industrialized areas of the world. Moreover, in light of the fact that the availability to natural resource is concentrated in specific areas of the world, it offers a significant increase to the volume of trade, since those industries lack the factor of mobility and impedes production relocation. The ever-increasing production and consumption of the modern world resulted in higher exploitation of those resources, impacting in the wealth of the country.

The Amazon Forest is a good example of the impact geography has in the natural resources. The Amazon Forest is home of $20 \%$ of world's fauna and flora and freshwater and its Hydrological Cycle feeds a complex that covers an area of nearly 4 million km2 (MRE, 2019). The forest extends its area throughout Brazil, Peru, Ecuador, Bolivia, Venezuela, Guyana, Colombia, Suriname and French Guyana. Due to its rich biodiversity, the area is explored in the pursuit of agricultural products, iron ore, gold, copper ore, petroleum gas, crude petroleum and others and all these countries' economies are well-known for their resource dependence. 
Based on the aspects described above, this paper has the goal to review the scientific literature on the impact of exports in the natural capital of a country. The contribution of this study is to bring a light on the scientific discussion on how natural capital can affect a country's wealth and how it should be better managed to guarantee its sustainability on the environment and on the economic health.

\section{SUSTENABILITY FOR CONTINUITY}

After Rio 92, The United Nations (UN) recommenced the discussion about global biosphere protection, that started in 1968 at the Paris Biosphere Conference, and at Rio+20, the United Nations Conference on Sustainable Development in 2012, the debate advanced, presenting by September of 2015, 17 Sustainable Development Goals (SDGs), which recognized poverty alleviation through providing easy access to education and healthcare infrastructure, rationale income distribution, tackling climate change, conservation of natural resources, and improving economic activities, by interlacing all those targets as an 'indivisible whole' and also, commitments were made in relation to green national income accounts (Helm, 2014; Nassani, et. al, 2019; Nilsson et al., 2016).

Sustainable development was defined then as development that meets the needs of the present without compromising the ability of future generations to meet their own needs. The critical principle underwriting sustainable development was that technology and social organization can both be managed and improved to allow ongoing economic growth that was within the planet's ecological means (Fenech et al., 2003). According to Barbier (2009), the economic development today must ensure that future generations are left no worse off than present generations or that per capita welfare should not be declining over time. Helm (2014) supports the idea of the need of a sustainable agenda, aligning development and nature, since the environment has been treated as an unnecessary constraint, "to be tamed to make way for humans, their crops, and their cattle". Horton et al (2016) affirms that the increase in production using current agricultural methods would greatly increase consumption of natural resources and will be unsustainable. Ottelin et al (2018), however, affirms that, despite of the idea that we can have economic, social and environmental sustainability at the same time, economists and ecologists disagree on whether economic growth is actually needed to tackle environmental problems or whether environmentally sustainable growth is an oxymoron. This point of view comes with the idea that, in the current economic model, the best clean technologies for the environment are not always profitable in economic terms, needing stronger environmental economic policies, such as carbon pricing, to enhance the development and implementation of clean technologies.

By contemplating sustainable development, it is being considered the planetary boundaries, which believes that, after a certain level of degradation, biophysical reproduction will no longer work. Nine processes are alleged to be necessary to define the planetary boundaries, being: climate change; rate of biodiversity loss (terrestrial and marine); interference with the nitrogen and phosphorus cycles; stratospheric ozone depletion; ocean acidification; global freshwater use; change in land use; chemical pollution; and atmospheric aerosol loading. Newer development plans must understand that the world's biophysical limits that are already being crossed and that it is impossible to imagine a planetary society in which all its members can consume as it is currently and the resources should only be managed efficiently, so that their stock 
of origin is not completely consumed. Megaprojects and current level of pollution are disrupting the vital cycles of nature and destroy the substantial elements of ecosystems, preventing their regeneration (Acosta \& Brand, 2018; Barbier, 2019; Andrade et al., 2012).

The expansion of globalization in the productive chain has being one of the main issues related to the degradation of natural resources, whether due to local comparative advantages of proximity to raw material, or cheap labor or other factors that make costs competitive, that increases the availability not only for cheap industrial products but also expanded industrialized agriculture (Acosta \& Brand, 2018). Consequently, globalization has also increased the exploitation of global workforce and natural resources, leading to a unprecedent extractivism, that has established a reductionist conception of nature, that reduces the complexity of biophysical networks and natural reproduction processes to mere "resources", which are freely available for exploration and commercialization (Acosta \& Brand, 2018). This severe exploitation only take place because of the high consumption level of modern society. Helm (2014) affirms that global consumption will increase around 30 times that of 2000 by 2100 and to balance such rhythm becomes a challenge and, although consumption has been growing exponentially, it does not mean that utility has also increased (Mueller, 2005), since it has been observed a greater preference in the possibility of consumption than in utility. Fernandes 2019) believes that consumption without exploitation is only possible if we eliminate this exploitation from the axes of capital production in its fullness, since local bubbles of sustainability can bring hope and inspiration, but they are still bubbles and, as such, are fragile and cannot be sustained by itself.

Within this context, Andrade et al (2012) brings the discussion that economics should reassess the main study objective of scarce resources and to see natural resource as a scarce factor, so that policies can be developed based on the tripod of ecological sustainability, social equity and economic efficiency and the allocation can be efficient and serve the supreme objective of economic growth, understanding it as the increase in goods and services available for the satisfaction of economic agents. However, defining what is sustainable and resource efficiency it is a challenge and the implementation of genuine and effective practice to bring this about is seriously compromised (Horton et al., 2016). Consequently, it is necessary to build new operational analytical schemes that make it possible to tackle the problem of sustainable and efficient management of natural resources based on the assumption that they is essential not only for the continuity of economic activities, but for the continuity of human life itself (Andrade et al., 2012; Andrade \& Romeiro, 2009).

\section{NATURE AS A FORM OF CAPITAL}

Capital in economics terms, refers to stocks of materials or information existing in a given period that generate service flows that can be used to transform other materials or their spatial configuration, contributing to the improvement of human well-being. This stock may increase or decrease over time, depending on the magnitudes of the inflows and outflows of the components of the stock (Costanza et al., 1997; Mueller, 2005). A company's equipment is a stock, and that the same can be said about all the machines, equipment and buildings in a country on a given date, computed by its balance sheet system and, when expressed in monetary terms, this is the country's fixed capital stock.

Fixed capital stock of a country incorporates elements as buildings, establishments, machi- 
nery, equipment, methods for transportation, draft animals and commercial livestock. If they function in the sphere of material production is considered fixed production capital; if they do not act directly in the production process constitutes fixed nonproduction capital. As a consequence, capital can also be defined as goods that are produced to produce other goods (Missemer, 2018). To make it simple, capital stock is a measure of the existing physical capital in an economy and, according to the economic theory, it should increase as it develops and grows richer. Capital stock is also part of a country's factor endowment, considered as the amount of land, labor, capital, and entrepreneurship that a country possesses and can exploit for manufacturing, that affects trade by creating a comparative advantage (Bajo-Buenestado, 2018). Thus, these factors can influence the geographical distribution of comparative advantage and, therefore, economies and trade. Based on input-factor mobility and production relocation, industries with relationship-specific assets tend to locate in countries with better institutions and considering relocating to areas geographically closer to their raw material. (BajoBuenestado, 2018; Jović et al., 2016).

By the end of the 20th century, a new term ceased to be just a metaphor used to draw attention to the problem of depletion of natural resources and became a formal and technical concept, used in conjunction with definitions of other types of capital, which is of the natural capital (Andrade \& Romeiro, 2009). This concept can also be understood as an economic production factor. If capital is the value of discounted future benefits or capital can be defined as physical systems with capacities and resilience, so natural resources can be considered part of a country's fixed capital stock (Recuero Virto et al., 2018). As a result, the rise of natural resource-based sovereign wealth funds among abundant nature resources economies is increasingly considered an important vehicle for improving their long-run economic performance (Barbier, 2019).

Missemer (2018) affirms that Auguste and Léon Walras in 1833 were one of the first to use the term "capital naturel", referring to original productive forces: land and labour, supported by Inhis Théorie that, in 1848, defined "capital naturel" as a synonym of primitive capital ("capital primitif') to refer to the value of the land. Fenech et al. (2003), in this context, affirms that the concept of natural capital is an attempt to integrate economics and ecology by conceiving the idea of 'nature' as 'capital'.

United Kingdom's Natural Capital Committee (NCC, 2014) defines Natural Capital as: 'The elements of nature that directly and indirectly produce value or benefits to people, including ecosystems, species, freshwater, land, minerals, the air and oceans, as well as natural processes and functions'. Mace et al (2015) defines natural capital as, literally, capital from nature, as a stock that has the power of producing further goods to benefit human societies and consider three as major types of capital: natural, human, and manufactured capital. Andrade \& Romeiro (2009) supports the concept of nature as capital by affirming that all economic production requires a physical flow of natural resources generated and this flow comes from its structural components, which can also be funds to produce other (intangible) benefits useful to human beings. The assets of nature, therefore, are all the species (including genetic variation), ecological communities, soils, freshwaters, land, minerals, the atmosphere, subsoil assets, coasts, oceans, as well as the natural processes and functions that underpin their operation. Missemer (2018) supports this concept of natural capital as the sum of exhaustible resources, renewable resources, and includes what are called today as the regulating ecosystem services (climate, hydrological cycles, etc.). Recuero Virto et al. (2018) affirms that natural capital relates both to 
non-renewable resources of the subsoil and to renewable resources, as well as to the associated services. Barbier (2011) establishes that, the concept of natural capital can be described as the components of the natural environment that can be used to generate income, goods or services. Pierce et al (1989) supports that natural capital underlines the role of nature in supporting the economy and human well-being. Andrade et al. (2012) also endorses that natural capital has a multidimensional character in which ecological, economic and socio-cultural dimensions are related and interact with each other for the promotion of human well-being.

This contribution is a particularly important aspect of the nature that gives support to human life. Besides provisioning material necessary for comfort and profit as food, water, timber, and fiber, nature provides regulating services, by providing natural protection against flood, drought, degradation, and disease; cultural services, by offering creational, aesthetic, and spiritual benefits and also supporting services such as soil formation, photosynthesis, and nutrient cycling (Patil, 2012). These services are known as ecosystem services, which can be described as the outcome of biological, geochemical and physical processes and components that take place within an ecosystem and that are available to people and may not be easily substituted by human and reproducible capital (Recuero Virto et al., 2018; Barbier 2019).

The concept of ecosystem services adopted here refers to the tangible and intangible benefits obtained by man through the dynamics and complex interactions between the different components of natural capital. Human knowledge about how the ecosystem functions emerge from the operation and interaction of structural elements of natural capital is very limited, but, in a simple way, a function is considered an ecosystem service when it has the possibility or potential to be used for human purposes (Andrade \& Romeiro, 2009). The so-called ecosystem functions are the result of complex interactions between the structural elements of natural capital and life on planet Earth is intricately linked to the continuous capacity to provide these services. When an ecosystem service is abundant in relation to its demand, a marginal increase in its flow represents only a small contribution to human well-being. However, when ecosystem service is relatively scarce, a decrease in its flow can substantially reduce well-being (Andrade \& Romeiro, 2009). The impacts of changes in the flow of ecosystem services on the constituents of well-being are complex and involve causal relationships that reinforce each other, mainly due to the interdependence of the processes of generating ecosystem services and between the very dimensions of well-being. Natural capital therefore includes all elements of the natural environment that provide benefits to people now and in future (Mace et al, 2015) and because they produce goods and services that support economic activity and enhance human welfare, those services are viewed as economic assets-or ecological capital (Barbier, 2019), and also are being recognized as the most significant political and scientific problem (Fenech et al., 2003).

Two are the general approaches to the theoretical integration of economic and ecological systems: first, an approach where the ecological systems are identified as being entrenched within the economy; and second, an approach in which the economy is understood as being rooted in ecological systems (Fenech et al., 2003). Thomas Malthus, who is credited with the famous relationship between population growth and food supply, can be considered the starting point of economic concerns about the scarcity of natural resources (Andrade et al., 2012). That concern comes from the higher position humans have in the nature's food chain, that is a complex part of ecosystems that, combined with collective human interests, leads to the ecological imperative of sustainability of the complex ecosystem(Fenech et al., 2003). Howe- 
ver, in economic theory, one of the most disputed subjects is the monetary valuation of natural capital, which attributes more relevance to costs and benefits in the present than in the future (Recuero Virto et al., 2018). Biodiversity, for example, may be both an asset and a benefit (Mace et al, 2015).

\section{EXPORTS IMPACT ON NATURAL CAPITAL}

One important element of natural resources is their geographical distribution, because neither natural resource nor economic activity are homogenously distributed. Some countries, that are abundant in natural resources before achieving some degree of industrialization, had a different growth and diversification trajectories than those where resource discoveries came later (Bahar \& Santos, 2018). This led to a comparative advantage that they made good use of, by providing the necessary materials for the industrialized world. And because the accessibility to natural resource is normally gathered in specific areas of the world that don't really correspond with the zones where those resources are incorporated to a production chain, it offers a significant increase to the volume of trade, since those industries lack the factor of mobility and impedes production relocation (González-Val \& Pueyo, 2019; Bajo-Buenestado, 2018). In many developing countries, a good use has been made of the strong growth in international demand for natural resources and, in some cases, have increased the export earnings and foreign investment (Acosta \& Brand, 2018).

The problem with comparative advantages that developing countries make such a good use of, is that they are presumably static, meaning that given the advantages of costs and prices and complementary productive efficiency, the countries have no incentive to change their supply and demand structures (Piorski \& Xavier, 2018). This is the reason why the literature many times projects natural resource wealth as either a curse or a basis of development. Throughout the second half of the last century, there was a growing consensus that natural resources were mainly bad for development, either for the long run shrinkage of relative prices or because positive price shocks displaced productive sectors (Manzano \& Gutiérrez, 2019). Resource abundance is also named as a "curse" by the literature, because of the inability it creates on those countries to take on the challenge of building alternatives to primary-export accumulation, despite its explicit failures (Acosta \& Brand, 2018). Overall, the economies that have created natural resource-based sovereign wealth funds are highly dependent on resource revenues (Barbier, 2019). Manzano \& Gutiérrez (2019) defines the resource curse as the overall net negative economic impact in resource producing regions and, sometimes, influencing nonproducing areas as well. This happens because the natural resources sector demands goods and services from the local economies, which means that it may also directly affect the economic performance of other sectors at the local level. The main problem, however, with resource-rich economies is the low elasticity-ingress that raw materials have, accompanied by the low technological contribution and little innovative development, which basically fix their prices by the logic of competition in the market: they are commodities (Acosta \& Brand, 2018).

Countries with large economic dependence on their natural resources and their exports, creates an environment of discouragement of other sectors. And the negative impacts of natural resource exports on non-resource tradable goods as an aggregate is referred by the literature as of Dutch disease (Bahar \& Santos, 2018). The Dutch disease is a long-term over appreciation of the exchange rate in countries that, due to commodity price booms, companies 
can profitably export at an exchange rate significantly more appreciated than that of industrial companies that use the best technology available in the world would require to be competitive. A non-neutralized Dutch disease is a major obstacle to industrialization and growth (BresserPereira, 2020). The exchange rate appreciation inhibits investments in tradable goods industries since the exchange rate makes imported products more competitive. Thus, the economic growth of a country that does not yet have a diversified industry could be compromised by the Dutch disease (Torres et al., 2015).

The "pure" Dutch disease causes deindustrialization, in the first place, by permanently appreciating the exchange rate in the long run. And when the Dutch disease comes along with the financialization of the economy, i.e., booming natural resource-oriented FDI and portfolio investment, such long-run exchange rate appreciation may be accompanied by medium-term exchange rate volatility and macroeconomic instability (Botta, 2017). The disease assumes that the high revenues from its exports of natural resources have implications for the reallocation of production factors, in the less competitive exchange rate for industrialized products, with negative effects on exports of these products and investments in the sectors. In a more longterm perspective, the situation is more problematic, first because the increase in wealth is not definitive and, second, industrial activities that disappear during the commodity boom cannot be resumed, permanently affecting growth possibilities of the countries (Piorski \& Xavier, 2018). The consequence of the Dutch disease would be the reprimanding of the economy or regressive specialization, that is, concentration of production on activities based on natural resources, in the first case, or in specific activities, such as labor-intensive manufactures, in the second (Torres et al., 2015).

The traditional models based on free trade, adopted by several developing countries, that are rich in natural resources, understand the comparative advantages as being the advantages of producing goods that one country has in relation to the other and seek to extract its advantages through the differences between prices or production costs of goods offered by countries in international trade. However, countries that have undergone import substitution models in their development models, still struggle to try to keep up with other industrialized countries, as they have established priorities linked to the verticalization of production within national borders, forgetting that, in addition to the availability of inputs, it is important a qualified workforce, infrastructure, in addition to subsidy and innovation policies (Piorski \& Xavier, 2018). In this way, international trade generates differences in income growth, since the relative advantage of one country vis-à-vis other countries, results not only from national differences in relation to the advantages of factorial endowment, but it is also a function of the technological differential, knowledge and capacity that are created and reproduced over time - the dynamic comparative advantages.

Another severe impact of natural resources exports is reflected in the environment itself. Environmental destruction is often the result of price policies for primary commodities that determine how individuals will use -- and abuse -- natural resources (Larson \& Bromely, 1991). That's the main reason why trade in natural resources is highly regulated, mostly on the export side, since about one-third of all export taxes cover natural resource sectors (Vézina, 2015). Natural capital, therefore, can be a method of putting nature in the center of economic thinking and be used as a way to measure economic progress (Mace et al, 2015). The over exploitation of the resources may have several impacts in long term, economically and biologically and the existing national and international arrangements for conserving global natural capital 
through market mechanisms need to incorporate local, social, political, legal and cultural complexities in their design and implementation

\section{ACCOUNTING FOR NATURAL CAPITAL}

The theory of public economics urges countries to collaborate on an environmental policy aimed at eliminating local, regional and global externalities affecting the environment, analyzing quality and the state of the stock of natural capital that serves as the basis for its generation, paying attention to restrictions regarding ecological sustainability, while ensuring economic development (Dasgupta, 2014; Andrade \& Romeiro, 2009). It is imperative to have the distinction between the nature of the components of natural capital to have a correct understanding of the dynamics of each type of resource, to be possible to take actions to protect the sustainability of the natural capital, as the depletion of structural components decreases tangible benefits and can represent an obstacle to the production and accumulation of other types of capital while also compromising ecosystem functions and the ability to generate intangible benefits (Andrade \& Romeiro, 2009; Andrade et al., 2012).

However, methods for accounting for natural capital as a stock, including the thresholds and the linkages to the economy, development and growth are currently underdeveloped (Helm 2014). The knowledge of the macroeconomic implications of environmental policies is low and not many models include the environment. This leads to the implicit assumption in contemporary macroeconomics, that there are no tradeoffs between environmental protection and aggregate employment. When environment is mainstreamed into economic accounts, it can advise analysis and development decisions. At the macroeconomic level, ministers of finance need to know whether or not their development strategies are laying the basis for longterm economic growth (Patil, 2012). Dasgupta (2014) affirms that without systematic research into the consequences for income and environmental externalities, societies will not put their minds to the question of how to link the two variables.

Fenech et al. (2003) affirms that this accounting for natural capital and its ecological systems in economic terms, will require turning away from neoclassical and Keynesian economics towards post-Keynesian decision theory since the value of ecological systems cannot be calculated in market terms on the basis of economic utility. Bateman et al. (2013) supports that a correct metrics should, ideally, reflect their contribution to human well-being and their input from productive or human capital. Although the values are often expressed in monetary terms, it is not sure if it is possible to generate robust estimates at all. Barbier (2019) and Patil (2019) defend that economies need to account for the depreciation of natural and environmental resources first, since these services are taken for granted and there is no estimation of what it would cost to the economy if these services were lost. Therefore, the best way to ensure the maintenance or increase of a wealth of an economy would be to re-invest the rents earned through natural resource exploitation to build up other economic assets and Helm (2014) supports by affirming that because the maintenance of assets at the aggregate level is not matched by the preservation of every particular asset, the principle of compensation needs to be rooted in the policy framework.

Natural capital accounting is a tool that can help measure the full extent of a country's natural assets and enables countries to measure the benefits and the cost of ecosystem changes. Without it, governments are underestimating the true contribution of their natural resource 
sectors (Patil, 2012). In other words, capital maintenance becomes the focus of accounting for our ability to meet the sustainability criterion (Helm, 2014). Recuero Virto et al. (2018) defines natural capital accounts as the (economic-)environmental accounts that refer to the statistics that can be integrated with national economic accounts which enable to have joint analyses. They can be used for macroeconomic and sectoral policymaking, provides time series data produced on a regular basis which enables analyses of trends over time and tools that facilitates joint analyses of environmental and economic data.

A natural capital plan for accounting begins with the assets which are in danger of crossing thresholds from being renewable to non-renewable, as a consequence, the next step is to consider the broader ecosystems and the landscape-wide features (Helm, 2014). Mace et al (2015) suggests a risk management that analyses the quantity, quality and spatial configuration of the assets available. Quantity describes the volume or mass that may also be relevant for some regulatory benefits, quality refers to a range of more specific conditions of the natural asset as habitat management or the presence of certain components or natural processes and spatial configuration refers to the location of the asset and/or its spatial patterning and fragmentation, both of which have been shown to have substantial effects on benefits.

The accounts can help assess aspects as the value of competing land uses that can help determine the full value of protected areas by adding up the potential contribution from tourism, climate regulation, and water supply provision or to determine how the management of coastal ecosystems can be improved and who will benefit. The identification of the target or limit for each asset-benefit relationship is a key step in developing the risk register of the ecosystem. A number of countries are already compiling accounts for water, energy, and minerals to be able of a better management or to evaluate the trade-offs needed for making different development decisions.(Mace et al, 2015; Patil, 2012). Fenech et al. (2003), on the other hand, criticizes the idea of a national and international accounts being expressed in monetary values for it reflect only the usefulness or utility of ecosystems and species in economic production and while ecological systems and species may have an 'intrinsic value', it is not clear how to measure such values so that they are comparable with market or pure economic values.

\section{THE RELEVANCE OF THE AMAZON FOREST}

The Amazon is the biggest tropical forest in the world. It is responsible for the life of innumerous ecosystems and provides a serious of ecological services necessary for human life and well-being. Rainforests perform a crucial role in conservation of biodiversity and convey essential ecosystem services as providing food and clean water, regulating climate and disease, supports soil formation, besides cultural and spiritual benefits (FAO, 2019) to indigenous and traditional populations as well as for the entire society. Rainforests are also important carbon sinks and have been receiving an ever-growing attention especially in the fight against climate change (Hargrave \& Kis-Katos, 2013).

The Amazon forest accounts for $40 \%$ of South America territory and, although the biggest area is in Brazil, it also stretches through other 8 countries, namely: Ecuador, Bolivia, Colombia, Venezuela, Guyana, Suriname, French Guiana and Peru. The forest is home of innumerous ecosystems and harbors $20 \%$ of world's fauna and flora and freshwater. Its Hydrological Cycle feeds a complex that covers an area of nearly 4 million $\mathrm{km} 2$ (MRE, 2019). The forest is 
source of one-fifth of all freshwater on the plane, discharging into the Atlantic Ocean, influencing large ocean currents that are important climate system regulators (Tigre, 2019). And approximately eight trillion tons of water evaporate from Amazon forests each year, with important influences on global atmospheric circulation (Nepstad et al., 2008).

The countries graced by the Amazon Forest share countless challenges and opportunities. Besides being home for the Amazon, those countries have as similar aspects to their economies, the strong dependence on natural resources. Most of the countries exports share are based in minerals, agriculture and some other natural products as timber and plants for pharmaceutical projects.

Another shared aspect of Amazon area is the deficient property rights guideline, where large areas of the Amazon forest, particularly in Brazil, can be as yet considered as zones of relative open access, leading to illegal use and deforestation (Hargrave \& Kis-Katos, 2013). And given the expected growth in population, housing stock, and the development of lots of additional infrastructure, there will inevitably be more environmental damage(Helm, 2014). However, the main problem is that the environment continues to be treated as an unnecessary constraint (Helm, 2014), where the natural capital should be explored, neglecting the sustainability aspect.

The forest is undoubtedly a source of extreme wealth for the countries who share its resources. The correct management of it can imply in long term economic success. The challenge here is to explore considering the nature as a source of capital that its not reproducible by human beings and not always replaceable.

\section{CONCLUSION}

This paper aimed to discuss the foundation of the discussion related to natural capital and the impact that exports have on it. Being the components of the environment that can be used to generate income, goods or services, natural capital is crucial for many countries' economies, but it is also essential for human well-being. We discussed the origin of the concern related to environmental resources, how it is intricately relevant for economies and industries and how, as being used to improve development, it can also lead to depletion of a country's wealth.

Natural resources, because of the potential in production of products and also of its ecosystem services, in providing the necessary aspects for human life and well-being composes what has been discussed as part of a fixed capital of a country, named as natural capital. It is the primary wealth of a society. Unfortunately, some countries rely too much on the extractivism of their most abundant assets and creates an economic dependence, by not encouraging diversification of the economy. This exploitation leads to severe impacts on the environment that it is not always reversive. In the long run, this can lead to the depletion of the resources of the country, leading to the loss of fixed capital stock and no alternative for economic diversification, accompanied of biodiversity losses and other ecosystem impacts, that may be irreversible.

The analysis of nature as a capital resource is of special relevance for countries that share the Amazon Forest and its resources. The correct management of it can imply in long term economic success. The challenge here is to explore considering the nature as a source of capital that it's not reproducible by human beings and not always replaceable. Because this is a theoretical foundation of the impact exports have on natural resources, a quantitative research is 
necessary to evaluate the length of the impact it can have in resource rich countries. Also, it can be suggested different methodologies for a richer theoretical research.

\section{BIBLIOGRAPHY}

Acosta, A., \& Brand, U. (2018). Pós-extrativismo e decrescimento: Saídas do labirinto capitalista (1o ed). Editora Elefante.

Andrade, D., \& Romeiro, A. (2009). Capital natural, serviços ecossistêmicos e sistema econômico: Rumo a uma "Economia dos Ecossistemas". IE/UNICAMP, 159. http:/ /www.eco.uni camp.br/images/arquivos/artigos/1789/texto159.pdf

Andrade, D., Romeiro, A., \& Simões, M. (2012). From an empty to a full world: A nova natureza da escassez e suas implicações. Economia e Sociedade, 21(3), 695-722. http://dx.doi. org/10.1590/S0104-06182012000300009.

Bahar, D., \& Santos, M. A. (2018). One more resource curse: Dutch disease and export concentration. Journal of Development Economics, 132, 102-114. https://doi.org/10.1016/ j.jdeveco.2018.01.002

Bajo-Buenestado, R. (2018). Relationship-specificity, incomplete contracts, and the pattern of trade: A comment on the role of natural resources. Energy Economics, 75, 410-422. https:// doi.org/10.1016/j.eneco.2018.08.032

Barbier, E. (2011). Capitalizing on Nature: Ecosystems as Natural Assets. Cambridge University Press.

Barbier, E. (2019). The concept of natural capital. Oxford Review of Economic Policy, 34(1), 14-36. https://doi.org/doi:10.1093/oxrep/gry028

Bateman, I. J., Harwood, A. R., Mace, G. M., Watson, R. T., Abson, D. J., Andrews, B., Binner, A., Crowe, A., Day, B. H., Dugdale, S., Fezzi, C., Foden, J., Hadley, D., Haines-Young, R., Hulme, M., Kontoleon, A., Lovett, A. A., Munday, P., Pascual, U., ... Termansen, M. (2013). Bringing ecosystem services into economic decision-making: Land use in the United Kingdom. Science (New York, N.Y.), 341(6141), 45-50. https://doi.org/10.1126/science. 1234379

Botta, A. (2017). Dutch Disease-cum-financialization Booms and External Balance Cycles in Developing Countries. Brazilian Journal of Political Economy, 37(3), 459-477. https:// doi.org/10.1590/0101-31572017v37n03a01

Bresser-Pereira, L. C. (2020). A armadilha da liberalização: Por que a América Latina parou nos anos 1980, enquanto o Leste da Ásia continuou a crescer? Brazilian Journal of Political Economy, 40(2), 405-410. https://doi.org/10.1590/0101-31572020-3125

Dasgupta, P. (2014). Natural capital in the macroeconomy. Environment and Development Economics, 19(3), 307-311. https://doi.org/10.1017/S1355770X14000254

FAO. (16 de November de 2019). Ecosystem Services \& Biodiversity (ESB).Fonte: Food and Agriculture Organization of the United Nations: http://www.fao.org/ecosystem-servicesbiodiversity/en/

Fenech, A., Foster, J., Hamilton, K., \& Hansell, R. (2003). Natural Capital in Ecology and Economics: An Overview. Environmental Monitoring and Assessment, 86(1), 3-17. https://doi.org/10.1023/A:1024046400185

Fernandes, S. (2019). Sintomas Mórbidos. (1o ed). Autonomia Literária.

González-Val, R., \& Pueyo, F. (2019). Natural resources, economic growth and geography.

PRACS: Revista Eletrônica de Humanidades do Curso de Ciências Sociais da UNIFAP

https://periodicos.unifap.br/index.php/pracs ISSN 1984-4352 Macapá, v. 13, n. 2, p. 17-30, jul./dez. 2020 
Economic Modelling, 83, 150-159. https://doi.org/10.1016/j.econmod.2019.02.007 Hargrave, J., \& Kis-Katos, K. (2013). Economic Causes of Deforestation in the Brazilian Amazon: A Panel Data Analysis for the 2000s. Environ Resource Econ 54: DOI 10.1007/s10640012-9610-2, 471-494.

Helm, D. (2014). Taking natural capital seriously. Oxford Review of Economic Policy, 30(1), 109-125. https://doi.org/doi:10.1093/oxrep/gru005

Horton, P., Koh, L., \& Guang, V. S. (2016). An integrated theoretical framework to enhance resource efficiency, sustainability and human health in agri-food systems. Journal of Cleaner Production, 120, 164-169. https://doi.org/10.1016/j.jclepro.2015.08.092

Larson, B. A., \& Bromely, D. W. (1991). Natural resources prices, export policies, and deforestation: The case of sudan. World Development, 19(10), 1289-1297. https://doi.org/10. 1016/0305-750X(91)90074-R

Mace et al. (2015). Towards a risk register for natural capital. Journal of Applied Ecology, 52, 641-653. https://doi.org/10.1111/1365-2664.12431

Manzano, O., \& Gutiérrez, J. D. (2019). The subnational resource curse: Theory and evidence. The Extractive Industries and Society, 6(2), 261-266. https://doi.org/10.1016/j.exis.2019. 03.010

Missemer, A. (2018). Natural Capital as an Economic Concept, History and Contemporary Issues. Ecological Economics, 143, 90-96. https://doi.org/10.1016/j.ecolecon.2017.07.011

MRE. (2019). Amazon Cooperation Treaty Organization-ACTO [Brazilian Ministry of Foreign Affairs]. http://www.itamaraty.gov.br/en/politica-externa/integracao-regional/6351amazon-cooperation-treaty-organization-acto

Mueller, C. (2005). O Debate dos Economistas sobre a Sustentabilidade - Uma Avaliação sob a Ótica da Análise do Processo Produtivo de Georgescu-Roegen. EST. ECON., 35(4), 687713. https://doi.org/10.1590/S0101-41612005000400004

Nascimento, D. M. (2010). Padrões geopolíticos presentes na defesa da Amazônia. Cadernos ADENAUER, 4, 71-83.

Nassani, et. al, et. al. (2019). Management of natural resources and material pricing: Global evidence. Resources Policy, 64, 1-9. https://doi.org/10.1016/j.resourpol.2019.101500

NCC. (2014). Natural Capital Committee's second state of natural capital report (No 2; p. 86). Department for Environment, Food \& Rural Affairs. https://www.gov.uk/government/publications / natural-capital-committees-second-state-of-natural-capital-report

Nepstad, D. C., Stickler, C. M., Filho, B. S.-, \& Merry, F. (2008). Interactions among Amazon land use, forests and climate: Prospects for a near-term forest tipping point. Philosophical Transactions of the Royal Society B: Biological Sciences, 363(1498), 1737-1746. https://doi.org/10.1098/rstb.2007.0036

Nilsson, M., Griggs, D., \& Visbeck, M. (2016). Policy: Map the interactions between Sustainable Development Goals: Nature News \& Comment. Nature, 534, 320-322.

Patil, P. (2012). Moving beyond GDP : how to factor natural capital into economic decision making (Working Paper No 69612). World Bank.

Pierce et al, A. (1989). Blueprint for a Green Economy-David William Pearce, Edward Burr Barbier, Anil Markandya, Edward Barbier_Google Livros (Vol. 1). Earthscan. https://books.google.com.br/books/about/Blueprint_for_a_Green_Economy.html?id=jMTupDDeW Z8C\&redir_esc $=y$

Piorski, K. A. O. da S., \& Xavier, C. L. (2018). Especialização em recursos naturais e cadeias 
globais de valor (1995 e 2009)*. Economia e Sociedade, 27(1), 89-127. https://doi.org/10. 1590/1982-3533.2017v27n1 art4

Recuero Virto, L., Weber, J.-L., \& Jeantil, M. (2018). Natural Capital Accounts and Public Policy Decisions: Findings From a Survey. Ecological Economics, 144, 244-259. https://doi.org/10.1016/j.ecolecon.2017.08.011

Tigre, M. A. (2019). Building a regional adaptation strategy for Amazon countries. International Environmental Agreements: Politics, Law and Economics, 19(4), 411-427. https://doi.org/10.1007/s10784-019-09443-w

Torres, R. L., Cavalieri, H., Torres, R. L., \& Cavalieri, H. (2015). Uma crítica aos indicadores usuais de desindustrialização no Brasil. Brazilian Journal of Political Economy, 35(4), 859877. https://doi.org/10.1590/0101-31572015v35n04a10 